\title{
Community Social Empowerment in Zakat Community Development
}

\author{
${ }^{1}$ SRI FADILAH, ${ }^{2}$ MEY MAEMUNAH, ${ }^{3}$ NOPI HERNAWATI \\ Accounting Study Program, Faculty of Economics and Business, Universitas Islam Bandung, \\ Jl. Taman Sari No.1 Bandung Jawa Barat \\ email: 1'srifadilah03@gmail.com, 2mey_maemunah@yahoo.com,33nopi.hernawati@gmail.com
}

\begin{abstract}
A large portion of the zakat utilization program is something needed in order to have long-term benefits of zakat and to increase the socio-economic value of zakat funds, one of which is the community's social empowerment program. BAZNAS (the National Zakat Amil Agency) of West Java, which has an intermediary function, conducts the Zakat Community Development (ZCD) program to empower the community. This study aims to determine the profile of social empowerment in the ZCD program. The research method applied is a case study and descriptive approach with data collection techniques through observation, in-depth interviews, and documentation. The results show that the effectiveness of zakat utilization can be increased through community social empowerment programs that are carried out in stages, namely the stage of mental development, group activities, and capacity building activities. Such a method aims to divide the empowerment process and identify competencies and community development.
\end{abstract}

Keywords: zakat funds, baznas, zcd program

\section{Introduction}

Discussion on poverty both socially and economically is a topic that has been and still will be discussed by faith-based organizations in conducting social welfare services. The activities of these religious groups have existed several centuries ago with the main similarity related to humanitarian values (Adi, 2013). In this case, the activities require agents of change (those who make social change) and beneficiaries (those who receive services) or their target communities (Adi, 2013).

Accordingly, the government must be present to encourage and develop various policies and regulations, especially related to the achievement of social welfare. Here, the role of the government as an agent of change must be clarified and enhanced. The government must support various efforts, especially the development of small community businesses (MSMEs) in the form of home industry processing through related regional organizations and regulations to encourage companies to issue Corporate
Social Responsibility (CSR) funds. In the community, those religious-based nongovernment empowerment organizations exist to implement poverty alleviation programs through community empowerment or community development. This empowerment agency program is unique and different from the model carried out by the government through all its tools.

There are many problems faced by developing countries, especially social and economic problems. As one of the developing countries, Indonesia also faces the same problem, particularly, the province of West Java (Bappeda Jawa Barat, 2018). Solving this problem must involve many parties, one of them is BAZNAS of West Java Province. The role of West Java BAZNAS distribution and other zakat institutions have been considered effective because its performance indicators are only seen from the beneficiaries. On the other hand, the portion of empowerment is still in the range of $20 \%-30 \%$ (BAZNAS West Java Province, 2017). It is expected that the

Received: 2019-09-16, Revised: 2019-12-06, Accepted: 2019-12-30 
community social empowerment can solve various social problems in West Java.

BAZNAS is a non-structural government institution that can be considered to represent the presence of the state in the context of poverty alleviation and has created poverty alleviation programs. For BAZNAS of West Java Province, there is a mentoring activity program in the Zakat Community Development (ZCD) program throughout 2016, 2017 and 2018 in six cities/regencies in West Java (BAZNAS West Java Province, 2018).

Thus, it is necessary to design various methods of zakat-based social empowerment that are effective in minimizing the low performance of empowerment and maximizing the social value of zakat (Tampubolon et al., 2006). BAZNAS of West Java Province applies the social empowerment method of various stages that build and motivate the Mustahik (beneficiaries) community. The empowerment stages are considered new because there has only been 1 empowerment stage so far. Since the zakat utilization program has sustainable social and economic value, this empowerment program aims to optimize the sustainable aspects that can develop the social community. This study chose BAZNAS West Java Province because it has a Zakat Community Development (ZCD) program that aims to empower people from economic and social aspects.

Zakat is defined as an obligatory donation of a certain portion of a Muslim or business entity's income/wealth to those entitled to receive it in accordance with the Islamic law (Law 23/2011, Chapter 1 Article 1 Paragraph 2). The roles of zakat in development as stated in the 2016-2020 BAZNAS Strategic Plan (BAZNAS, 2016) are as follows: (1) the role of moderating social inequalities, (2) the role of popular economic revival, (3) the role in encouraging the emergence of breakthrough models in eradicating poverty and (4) the role of overcoming poverty through the synergy of various aspects.

Zakat Community Development or ZCD is a group empowerment program that integrates social aspects (education, health, advocacy, environment, and other humanities) with comprehensive economic aspects whose main funding comes from zakat, donation, and alms to create a prosperous and independent society. The indicators of Zakat Community Development (ZCD) (BAZNAS,
2013), in particular. can be explained as follows (1) To increase awareness and care of Mustahik beneficiaries about quality of life with indicators: (a) Increasing the number of people who donate zakat, infaq, and alms; (b) Increasing community activities in religious and social activities; (c) Increasing the number of community members who are able to read and write the Qur'an; (d) Increasing the number of community members who meet the Nutrition Adequacy Rate (RDA); e) Decreasing maternal and infant mortality rates; (f) Decreasing the number of community members suffering from malnutrition and other endemic diseases, for example, Tuberculosis, Cholera, Malaria, etc.; ( $g$ ) Decreasing the number of illiterate community members and children who leave school; (h) Increasing the congregation worship activities.

Indicator (2) To increase participation towards community independence with the following indicators of success: (a) Increasing the number of community members who are actively involved in the program; (b) Increasing the number of non-governmental organizations supporting the community empowerment program; (c) Increasing the quality of people's knowledge, skills, and behavior; and (d) Increasing the income of community members (income per capita). Indicator (3) To increase social and economic networks with the following indicators: (a) Increasing the parties involved in implementing the program; (b) Increasing the number of people who have businesses, and (c) Decreasing the unemployment.

The last one is indicator (4) creating a sustainable empowerment program in realizing the welfare and independence of the community with the following indicators of success: (a) Expansion of the area and type of program; (b) Addition of program beneficiaries; (c) Increasing the success, benefits, and impacts of the program; and (d) Increasing the welfare and independence of the community (Riach, 2002) states that the assistance for micro small business groups aims to encourage the increased income for individual and group beneficiaries. The important principles of group assistance consist of (1) Participation, or participatory development is a basic principle of community development in accordance with the way the community wants while respecting local knowledge and talents. Sustainable community development ultimately depends on the participation of people from the 
initial planning stage to completion. (2) Sustainability, the principle of sustainable development is a basic principle of community development that is often hard to achieve. When a change is introduced to a community, it is expected that the community will adapt and maintain it. Some principles of sustainability include: (a) active participation of community members in all aspects of the project such as problem/needs identification, planning, implementation, monitoring and evaluation, (b) the use of appropriate technology to serve local needs. (3) Equity and social justice, namely the principle of community development based on equality and social justice with the aim that: (a) all members of the community, regardless of their culture, religion, gender or age, have the opportunity to actively participate in the communities, (b) the availability to access the information in an understandable way, (b) justice for all people to access the community resources, (c) fulfillment of people's democratic rights to participate in all forms of community development.

The above explanation indicates the importance of the appropriate field approach to achieve economic group performance indicators. In its implementation process, the stages of intervention in local communities have variations. (Adi, 2013) mentions seven stages of intervention as follows: (1) Preparation stage, which consists of (a) preparation of officers to uniform their perception through the provision of techniques as executors, and (b) field preparation through formal/informal contact to reach the engagement phase with local personal. (2) Assessment stage, which is carried out to identify problems according to the needs through SWOT or PLA (participatory learning and action) techniques such as describing the problems and the potential of the community. (3) The alternative planning stage of the program which involves communities to think about the problems and the solutions in accordance with the purpose of providing assistance. (4) Formulation Phase of the Action Plan. At this stage, the facilitator helps each group to formulate and determine what programs and activities are appropriate for solving the problem. (5) Program Implementation Phase, program implementation will be very much determined by the participation of the communities. The active role of communities as local cadres is expected to make this activity a positive one and have a sustainable impact. (6) The stage of Evaluation Process and Results of Changes. Evaluation is part of supervision that relies on input, monitoring process, and output of intervention results. The last one is (7) Termination Phase. This stage is the end of formal relations with the target community. Termination often happens not because the community is independent, but rather because the project has run out of the fund or it has been a too-long project to accomplish. All the steps mentioned above are cyclical which can rotate to achieve the desired change together.

From the context of economic life, Muslims are always identified with poverty. Developing countries that are still laden with poverty are generally countries with a Muslim majority population. Apparently, in recent years in Indonesia, issues relating to the concept of implementing zakat both as a religious obligation in private and zakat as a component of public finance are very popular (Djailani, 2011). This is in line with the research results of (Memon, et al. 2015) which states that good zakat governance will have an impact on increasing public confidence and the collection of zakat funds.

Zakat institutions are obliged to manage zakat funds from muzaki (zakat giver) to be used wisely in accordance with their designation (Fadilah, et al: 2013). The zakat law states that the use of zakat aims to improve the standard of living of mustahik (zakat beneficiaries). In the Qur'an, it is explained there are eight Asnaf (the recipients of zakat that have been specified by Allah (S.W.T)), namely: Fakir (those who have no material possessions), Poor, Amil (those who are appointed to collect Zakat), Muallaf (those who recently embraced Islam), Riqab (those who are freeing themselves from shackles of slavery), Gharim (those who are in debt and needs assistance), FiSabilillah (those who strives in the cause of Allah) and Ibnussabil (stranded travelers on a permissible journey). There are two types of zakat distribution, namely consumptive and productive activities. Consumptive activity is the zakat program to solve short-term problems. While productive activities are zakat programs aimed at long-term and community empowerment. If these needs have been met or there are the remaining funds, they can be allocated to productive business activities through a continuous empowerment program (Fadilah, et al: 2015); (Harahap, 2012). This research supports other research that discusses the performance of zakat program as conducted by (Riach, 2002) who stated that community 
empowerment can be seen from several aspects.

\section{Research Methodology}

The research method used is the case study in BAZNAS West Java which explains one case, namely the community social empowerment program in the zakat-fostered community development area of Bandung Barat (West Bandung) Regency. The research approach applied is descriptive analysis research. This study consists of one variable, namely community economic empowerment based on zakat funds. The data collection technique used is observation, which is a research technique using the sight sense to an object/research variable of empowerment activities in Citades, one of the target areas in Bandung Barat Regency (KBB), West Java. An in-depth interview is a data collection technique through interviews with parties related to an object/research variable. In this study, researchers interview the beneficiaries of the zakat empowerment program (mustahik), empowerment assistance (Amil) program from Citades, leaders and heads of program divisions at BAZNAS West Java Province.

The next data collection technique is documentation, which is based on documents related to research objects, either document from Citades, West Java Province BAZNAS, as well as various articles and related regulations. The research location is in Citades, an empowerment area that implements the distribution and utilization program of West Java Province BAZNAS in Bandung Barat Regency, with the reason that it is close to campus and can be a target area of Universitas Islam Bandung.

\section{Results and Discussion}

\section{Profile of the National Amil Zakat Agency (BAZNAS) of West Java Province}

BAZNAS of West Java Province was first originated from the UPZ (Zakat Collecting Unit) in the West Java Provincial Government to collect ZIS (Zakat, Infaq, Sodaqoh/alms) funds from civil servants and employees in the West Java Provincial Government with the ideal slogan of 'from them for them'. Then, during the leadership of $\mathrm{H}$. Ahmad Heryawan (Kang Aher), a former governor, it was strengthened by the Governor's Regulation and the continuous education about zakat awareness along with the inauguration of the
West Java BAZDA Board, so that ZIS fundcollecting was more optimal and spread to all civil servants who have reached the zakat nisab (threshold).

BAZDA (Regional Amil Zakat Agency) was first established in 1974, then it was renewed by the Decree of the Minister of Religion of the Republic of Indonesia Number 118 of 2014 and became the Provincial BAZNAS. In line with the division and development of province area in Indonesia, the former Decree was revised with the Decree of the Minister of Religion No. 186 of 2016 concerning Amendment Decree of the Minister of Religion No. 118 of 2014 concerning the establishment of the Provincial National Amil Zakat Agency. The Chairperson of West Java National Amil Zakat Agency was inaugurated based on West Java Governor Decree Number 450.12/Kep.156-Yansos/2015 concerning the Chairperson of National Amil Zakat Agency (BAZNAS) of West Java Province for the period of 2014-2019 on January 23, 2015. Then in 2016 , there was a change in the structure of the chairperson which made the former decree revised to the Decree of the Governor of West Java Number 450.12/Kep.919Yansos/2016 concerning Amendments to the Decree of the Governor of West Java Number 450.12/Kep.156-Yansos/2015 concerning the Chairperson of the National Amil Zakat Agency (BAZNAS) of West Java Province for the period of 2014-2019.

BAZNAS of West Java Province was established on January 26, 2015, with a Tax Identification Number (NPWP): 31,500,662.7423,000. BAZNAS of West Java Province is responsible for the Governor of West Java through the Regional Secretary and is responsible to BAZNAS (Central). The legal basis for BAZNAS is as follows: (1) Law Number 23 of 2011 concerning Management of Zakat and (2) Government Regulation Number 14 of 2014 concerning the implementation of Law No. 23 of 2011 concerning Management of Zakat.

One of the intermediary roles of zakat is the distribution consisting of the distribution and utilization of zakat. Zakat distribution covers the fields of health, economics, education, and charity. Each zakat institution can brand its programs according to local characteristics, coverage, and content. In recent decades, many zakat institutions have developed zakat distribution programs in accordance with the needs of stakeholders and the development of an area. The program 
designed covers the following fields: Health Assistance Service, Education Assistance Service, Mustahik Empowerment Service, religious Service, Social and Humanitarian Service. The following are programs for utilizing zakat fund of West Java BAZNAS:

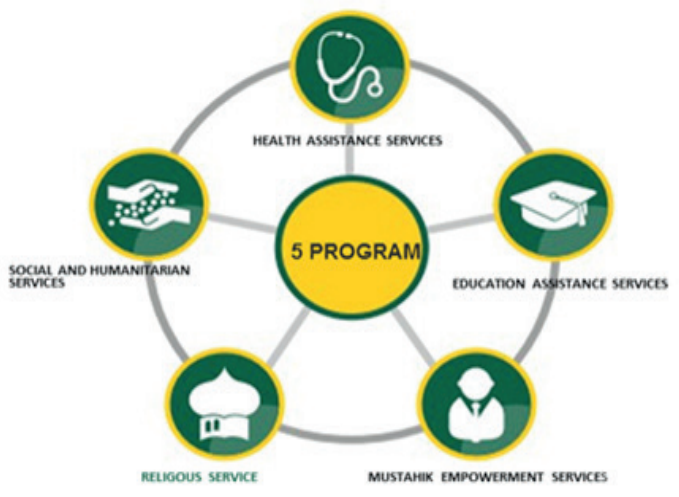

Figure 1. Zakat Program of West Java BAZNAS

The main aspect in designing zakat utilization program is the utilization of social and economic value of zakat, namely the effectiveness level of the use ofzakat in accordance with the allocation of funds, namely philanthropy of religious funds (Harahap, 2012). A basic factor to achieve the utilization of social and economic value of zakat is regional superiority. This factor is very suitable to be applied in West Java (Jabar) because of its superiority in each region and the good level of creativity of Jabar residents (BAZNAS Jabar, 2017). Regional excellence as the basis for zakat utilization include: equitable distribution of regional welfare, increasing regional competitiveness, alleviating regional poverty, and achieving the effectiveness of zakat utilization to get the maximum benefits of zakat's socio-economic values (BAZNAS Jabar, 2017).

\section{The Profile of Yayasan Cinta Desa (Citades)}

Law No. 23 of 2011 on Zakat Management requires the West Java BAZNAS to carry out the role of zakat intermediation. The distribution role consists of zakat distribution and utilization of zakat. Community empowerment is a model implemented in West Java BAZNAS with one of zakat fund empowerment models covering seven scopes spread across West Java cities and districts, namely Bandung Barat Regency, Bekasi City, Bokor Regency, Bogor Regency,
Subang Regency, Garut Regency and Subang Regency. These areas have the potential for creation and learning so that they are good enough to be developed. Citades selects and establishes target communities that have the potential to develop so that they can be empowered. There are 2 aspects of empowerment, namely human empowerment and program empowerment (BAZNAS West Java, 2016). Human empowerment consists of strengthening the aqidah (Islamic creed), morals, and muamalah (social life); increasing the competence and skills; building networking; improving communication skills; building mentality of giving and sharing; helping and increasing creativity and innovation.

The empowerment program consists of Jabar Sehat, Jabar Mandiri, Jabar Pintar, Jabar Takwa and Jabar Peduli. At the implementation stage, since this is the empowerment of the community, the limited number of Amil (there is only one) becomes the biggest obstacle. Below are a number of empowerment activities in the economic and social fields that have been carried out at the target area of Bandung Barat Regency.

\section{Community Social Empowerment at Fostered Area of West Java BAZNAS in Bandung Barat Regency}

BAZNAS of West Java Province as an intermediary institution has the task to collect zakat funds from Muzaki and distribute them to Mustahik. Mustahik in question consists of 8 Asnaf, namely fakir, miskin, amil, mualaf, riqob, ghorimin, fisabilillah and ibnusabill. The role of zakat in development as stated in the 2016-2020 BAZNAS Strategic Plan, (BAZNAS, 2016). mentioned as follows: (1) The role of $z$ akat intermediation is to moderate social inequalities that can be carried out significantly in the distribution of wealth, namely from muzaki to mustahik with amil zakat as intermediaries; (2) The role to encourage the rise of popular economy; (3) The role to create and innovate zakat program with the aim to encourage the emergence of a breakthrough model in poverty alleviation; and (4) Zakat is a source of funding for the development of people's welfare outside the State Budget or Regional Budget.

If being optimized, the potential of this zakat fund $\mathrm{c}$ an be a complement to the poverty reduction program agenda that can be done through synergy. It is obvious 
that BAZNAS of West Java Province has the purpose of increasing the social value of zakat being distributed. Zakat distribution program in BAZNAS of West Java Province is divided into two activities, namely the distribution and utilization of zakat. There are several fields that are empowered by BAZNAS of West Java Province, namely: social, economic, health, education, religion, and disaster. Those fields are branding as follows: (1) JabarPeduli (Caring), (2) JabarMandiri (Economic), (3) Jabar Sehat (Healthy), (4) Jabar Cerdas (Education), (5) JabarTakwa (Religion) dan (6) Jabar Baznas Tanggap Bencana ( $\mathrm{BTB}=$ Rescue) (Jabar Disaster Response). With so many fields empowered, it will be able to empower society as a whole. Ideally, the West Java Province BAZNAS has 27 fostered areas since there are 27 cities and regencies in West Java Province. However, at present, it only has 6 (six) fostered areas spread throughout West Java. The empowerment program in the target area is called the Zakat Community Development (ZCD) program. BAZNAS fostered areas in West Java Province are spread in the following cities and regencies: Bandung Barat Regency, Garut, Subang, Bogor and Bogor City, Bekasi City.

To make this empowerment program successful and to increase the effectiveness of the Zakat Community Development (ZCD) program, BAZNAS West Java Province places one program worker or volunteer in each of the target areas. The chosen volunteers from BAZNAS partners have the competencies needed for community empowerment, but they are lack in number. This problem added by the lack of expertise in the required fields such as marketing management, financial management, business management, accounting, and entrepreneurship. For this reason, collaboration and partnership are needed from many stakeholders of BAZNAS in West Java Province to overcome these problems.

This research took a case study on Zakat Community Development (ZCD) program in Bandung Barat Regency. Table 1 shows the reasons for the selection and profile of the Zakat Community Development (ZCD) Program in West Bandung Regency.

Furthermore, the community empowerment program is carried out with empowerment activities as follows: (1) Assistance for Mustahik to become Muzakki, and (2) Assistance in all aspects of the business including management, finance, operations, control and reporting.

Table 2 shows the program developed by the Citades Foundation in Bandung Barat Regency in empowering the community by applying a tiered/stages method consisting of stages of mental development, group activities, and increasing the capacity to be independent.

The empowerment of Citades foundation by this tiered/stages model began in 2017 and is now in its second year. Table 3 shows the results of community empowerment under the Citades foundation at each stage and year for the social sector.

The community must understand that this social sector is important because community empowerment comes from zakat funds, namely religious social funds (Yudan, et al., 2016). For this reason, these funds must be used maximally for empowerment with the long-term goal of transforming the Mustahik into Muzaki.

Systematic and effective stages of community social empowerment programs, particularly in the Zakat Community Development area of West Java BAZNAS, are empowerment models that have a high level of effectiveness since they are able to achieve the goals of social empowerment. Community social empowerment aims to make the community have an empowerment mentality such as being independent, having an entrepreneurial spirit, and being participatory, which can eventually transform oneself from Mustahik to Muzaki. The added value of these stages of empowerment is the mustahik (beneficiaries) mental readiness to be more resilient and work harder in running a business when experiencing capital termination and not giving up in facing various business obstacles. The long-term benefit of the stages of the empowerment program is the high chances of Mustahik (beneficiary) to succeed.

The results of observations and interviews revealed a number of obstacles experienced by volunteers and fosteredcommunity of Citades Foundation in the implementation of community social empowerment programs. These constraints are summarized in table 4.

If those constraints are not being anticipated immediately, they will disrupt and hinder the effectiveness of this social empowerment program. The solution offered by BAZNAS West Java is to add the number 
Table 1

Reasons for the Selection and Profile of Zakat Community Development (ZCD) Program in Bandung Barat Regency

\begin{tabular}{lll}
\hline No & $\begin{array}{l}\text { Reason to choose location of Zakat } \\
\text { Community Development (ZCD) }\end{array}$ & $\begin{array}{l}\text { Profile of Zakat Community Development } \\
\text { (ZCD) Program }\end{array}$ \\
\hline 1 & $\begin{array}{l}\text { West Java BAZNAS partner is the Citades Foundation, } \\
\text { a partner committed to carrying out an empowerment } \\
\text { program }\end{array}$ & $\begin{array}{l}\text { It aims to transform the Mustahik in to Muzakki. } \\
2\end{array}$ The location is less than $200 \mathrm{~km}$ from Unisba campus $\begin{array}{l}\text { It has a variety of businesses or fields of empowerment } \\
\text { and is very cooperative with program volunteers in } \\
\text { community empowerment }\end{array}$ \\
3 Support from regional government and village & $\begin{array}{l}\text { It has the most number of empowerment participants } \\
\text { compared to other Zakat Community Development } \\
\text { (ZCD) locations, which is } 110 \text { members }\end{array}$ \\
\hline
\end{tabular}

Table 2

Fostered-Community Empowerment Program in Bandung Barat Regency

\begin{tabular}{lll}
\hline No & Stages of Empowerment & Description \\
\hline 1 & Mental development & It is an activity aims to prepare the target communities to become \\
& & entrepreneurs according to their respective fields and interests \\
& Change the mindset of fostered-community from ordinary to \\
& entrepreneurial or business communities.
\end{tabular}

At this stage, the fostered-community carries out recitation and development of Islamic study groups, cleaning the mosques, PKK ladies, youth clubs, farmer groups, etc.

2 The same-interest group activities

It is an activity carried out by forming groups with the same or almost the same interests. For example, doing a simple business, farming, raising livestock, handling the environment, and others. This group is formed to strengthen togetherness and friendship.

At this stage, the community group is given knowledge and skill in accordance with their interest with the aim of getting ready for the business. At this stage, BAZNAS of West Java Province has also provided venture capital. The amount of capital is usually given by considering the ability and capacity of the beneficiary groups.

3 Activities to increase capacity

It is an activity undertaken to further develop the potential of groups that have been formed. Here, creativity and innovation are needed to develop a business.

of Amil volunteers for the program. However, it is not enough because, quantitatively, it is still unable to meet the number of personnel needed for mentoring and monitoring activities. It is expected that these constraints can be minimized by adding volunteers and experts who have competence and skills, either from BAZNAS, Citades, and other volunteer communities such as universities.

Minimizing the obstacles in the community social empowerment program, especially in the fostered-area of West Java Province BAZNAS in Bandung Barat, can be done in the following ways: (1) Conducting further research related to the model of community empowerment based on regional excellence. (2) Providing community service (PKM) as a continuation of the Community
Empowerment Model based on zakat funds. Activities in the Community service activities (PKM) is in the form of (a) Socialization of community empowerment models based on zakat fund. (b) Providing various training to assist the Citades foundation and West Java BAZNAS in reducing and eliminating the constraints of community empowerment programs. (3) Collaborating with BAZNAS of West Java Province and the Ministry of Religion of West Java in the field of Islamic information, zakat, and waqf (Penaiszawa), to socialize, provide training and assistance for the implementation of community empowerment models based on zakat funds in BAZNAS of cities and regencies in West Java. (4) involving companies as part of the wider community through Social Corporate Responsibility (CSR) program. 
Table 3

Results of Fostering in Stages and Year of Social Field

\begin{tabular}{|c|c|c|c|}
\hline Stages/Year & 2017 & 2018 & 2019 \\
\hline $\begin{array}{l}\text { Mental } \\
\text { development }\end{array}$ & $\begin{array}{l}\text { Initiation for group } \\
\text { formation with activities in } \\
\text { the fields of religion, social } \\
\text { service, training, etc. }\end{array}$ & $\begin{array}{l}\text { To include activities aiming at } \\
\text { fostering mental which already } \\
\text { exists in groups formed in the } \\
\text { first year }\end{array}$ & $\begin{array}{l}\text { The still ongoing mental } \\
\text { training activities }\end{array}$ \\
\hline Group activities & $\begin{array}{l}\text { Start to form a group of: } \\
\text { (a) Recitation in } \\
\text { majelis taklim, (b) PKK } \\
\text { activities, (c) posyandu, } \\
\text { (d) karang taruna (youth } \\
\text { club) and (e) Farmer } \\
\text { groups }\end{array}$ & $\begin{array}{l}\text { Start to assess each group } \\
\text { with interest in social activities } \\
\text { such as Al-Quran recitation, } \\
\text { social service, etc }\end{array}$ & $\begin{array}{l}\text { Finalising in groups in } \\
\text { the hope to form mental } \\
\text { readiness }\end{array}$ \\
\hline $\begin{array}{l}\text { Activities to } \\
\text { increase the } \\
\text { capacity }\end{array}$ & -- & $\begin{array}{l}\text { Finalising plan of social } \\
\text { activities that have an impact } \\
\text { on leadership and business } \\
\text { formation. } \\
\text { Social mental development } \\
\text { aims to support mental } \\
\text { readiness in running the } \\
\text { business. } \\
\text { Mental resilience is expected } \\
\text { to be a factor in the success of } \\
\text { future businesses. }\end{array}$ & $\begin{array}{l}\text { Building group } \\
\text { independence before being } \\
\text { released as an independent } \\
\text { community group to be } \\
\text { empowered }\end{array}$ \\
\hline
\end{tabular}

Table 4

Obstacles to Economic Empowerment Based on Zakat Funds

\begin{tabular}{|c|c|c|}
\hline No & Obstacles & Description and Solution \\
\hline 1 & $\begin{array}{l}\text { Lack of staff who have the required competence } \\
\text { and the limited number of assistants/companions }\end{array}$ & Constraints in the number and variety of competencies \\
\hline 2 & $\begin{array}{l}\text { The lack of parties/partners and business } \\
\text { networks that support the success of the program }\end{array}$ & $\begin{array}{l}\text { Invite more stakeholders such as universities and } \\
\text { government institutions as well as the public. }\end{array}$ \\
\hline 3 & $\begin{array}{l}\text { Material that must be added and modified related } \\
\text { to innovation and creation }\end{array}$ & $\begin{array}{l}\text { An opportunity for lecturers, students, and other } \\
\text { communities to serve the community }\end{array}$ \\
\hline
\end{tabular}

The West Java BAZNAS' community social empowerment program shows that focus of zakat is not only about distributing zakat but also the utilization of zakat which has a more structured benefit in the long term (Fadilah et al. 2017) This is in line with the research results of (Siregar, 2007) who states that community social empowerment is a program that has the benefit of program structure and a long-term time. Furthermore, zakat funds can be used to solve various social problems such as unemployment and poverty, not only in West Java but also in Indonesia and even the world. It can be seen that to achieve the SDG's goal, it has already included elements of social funds including zakat funds. Thus, it is in accordance with the law that zakat is Islamic philanthropy which should be used to solve social problems, especially poverty, social, dakwah, economic, health, etc. The more useful the value of zakat in solving people's problems, the higher the social and economic value of the use of the zakat.
Finally, it can be said that the community social program in zakat community development (ZCD) in fostered-area of Bandung Barat Regency which applied 3 stages, namely the mental development stage, the group activity stage, and the activity phase to increase capacity is more effective compared to the one-stage method. This is because the three-stage community empowerment program is an effective program that is able to achieve the objectives of the community's social empowerment.

\section{Conclusions}

Based on the above discussion, the results of research on community empowerment in the community development zakat program (ZCD) in the fostered-area of Bandung Barat Regency can be concluded as follows: (1) The intended community empowerment field is social. It means a social condition of the beneficiaries or mustahik 
who will be prepared for the economic empowerment. 2) The effectiveness of tiered/ stages of community social empowerment, namely: the stage of mental development, the stage of group activities, and the stage of activities to increase capacity. These stages are carried out before capital initiation for an economic program. The socio-economic empowerment program with 2 programs is a continuous improvement compared to a stage program of direct capital initiatives. (3) In its implementation, there are several obstacles, namely the limited number of assistants/ volunteers and experts who support the utilization of zakat activities, especially social empowerment of the community. Surely, there must be solutions for the problems by involving many parties and communities.

The recommendation of this research is that it should involve many stakeholders such as universities, government, students, and the wider community in the form of community service, especially social empowerment based on zakat funds. To anticipate the obstacle, there should be wider community that helps this empowerment program, such as universities with community service programs (PKM) and companies through the Corporate Social Responsibility (CSR) program.

\section{Acknowledgment}

The researchers would like to thank LPPM Unisba for providing research funding and the opportunity for researchers to conduct research with the aim of continuing the existing research roadmap. We hope the results of this study can provide benefits for zakat managers to improve the performance of zakat distribution programs, and also for the community, in general, to get information/ knowledge from this research. We also hope that the results of this research can help UNISBA in implementing the master plan of research and community service.

\section{References}

Adi, I.R. (2013). Kesejahteraan Sosial. Jakarta: Rajagrafindo Persada

BAZNAS (Badan Amil Zakat Nasional Jawa Barat) (2017), Strategic Zakat Plan. 20162020. 2017

Bappeda Jawa Barat.(2018). Poverty Data from West Java. West Java Provincial Government

Djailani, (2011). DKI Bazis Strategy in Getting
Around the Implementation of Law No. 23 of 2011 concerning Management of Zakat, Zakat Forum (FoZ).

Fadilah, S., Lestari, R., \& L, Nurcholisah, K. (2013), Implementation of Good Governance: Study in Lembaga Amil Zakat Indonesia. International Journal of Applied Finance and Business Studies (IJAFBS) Vol. 1 No.2 October 2013 page. 39-54. Trigin Publisher

Fadilah, S., Lestari, R., \& L, Nurcholisah, K.(2015). Assessment of Organization Performance for Zakat Management Organization (Qualitative Approach). $3^{\text {rd }}$ IMCoSS 2015 Universitas Bandar Lampung. 5-7 June 2015.

Fadilah, S., Lestari, R.,\& Rosdiana, Y. (2017). Administrator Policy: Important Factors of The Effectiveness of Zakat Utilization. Asia International Multidisciplinary Conference 2017 University Technology Malaysia (UTM) Johor Baharu Malaysia, 01-02 Mei 2017

Government Regulations Number 14 the Year 2014 on the implementation of Law No. 23, 2011 on Zakat Management

Harahap, E.F.(2012). Community Empowerment in the Field of Economy to Create a Strong and Independent National Economy. Journal of Management and Entrepreneurship, Volume 3, Number 2, Mei 2012 ISSN: 2086 - 5031. https:// s3.amazonaws.com/academia.edu. documents $/ 57532625 / 5$

Law Act No 23 the Year 2011 on Zakat Management

Memon, Jamshed, M. Z. A Rozan, Kamariah Ismail, Mueen Uddin, and Dzullkarnain Daud.2015 "Mentoring an Entrepreneur: Guide for a Mentor." SAGE, 2015: 1-10.

Ministry of Religion of the Republic of Indonesia (2014). Decree of the Minister of Religion Republic of Indonesia Number 118 of 2014 concerning the Establishment of Amil Zakat Body National Province

Ministry of Religion of the Republic of Indonesia (2016). Decree of the Minister of Religion of the Republic of Indonesia Number 186 of 2016 concerning Amendment to the Decree of the Minister of Religion Number 118 of 2014

Riach, M.(2002). "Understanding Community Development." In Community Development Strand, by Michael Riach. Papua New Guinea: Pastep, 2002.

Siregar.CN.(2007). Sociological Analysis of the Implementation of Corporate Social Responsibility in Indonesian Communities. Vol. 6 No. 12 (2007). 
Journal Sosioteknologi, Institut Teknologi Bandung.http://journals.itb.ac.id/index. php/sostek/article/view/984

Tampubolon, J. Basita GS, Margono. S, Djoko S \& Sumardjo. S.(2006). Community Empowerment through a Group Approach (Case of Empowering the Poor Through a Business Group Approach (KUBE). Journal penyuluhan. Vol. 2 No. 2 (2006). http:// jurnal.ipb.ac.id/index.php/jupe/article/ view/2122

Universitas Islam Bandung. (2015). Research Development Master Plan and Community Service 2015-2020.

West Java Provincial Government. (2015) West Java Governor Decree Number 450.12 / Kep.156-Yansos / 2015 concerning the Head of the National Amil Zakat Board (BAZNAS) of West Java Province for the
2014-2019 period.

West Java Provincial Government. (2015). West Java Governor Decree Number 450.12 / Kep.919-Yansos / 2016 concerning Amendments to the Decree of the Governor of West Java Number 450.12 / Kep.156-Yansos / 2015 concerning the Head of the National Amil Zakat Agency (BAZNAS) of West Java Province from 2014 to 2019

Yudan H, Yoyon S. (2016). Community participation in organizing programs for community learning activities Ngudi Kapinteran. Journal Pendidikan dan Pemberdayaan Masyarakat.Vol. 2 No. 3 (2016). ISSN. 2355.1615. https:// journal.uny.ac.id/index.php/jppm/article/ view/8111 